\title{
ELEMENTAL AND ISOTOPIC COMPOSITIONS OF ORGANIC CARBON AND NITROGEN OF RECENTLY DEPOSITED ORGANIC MATTER IN EMPAKAI CRATER AND ITS IMPLICATION FOR CLIMATIC CHANGES IN NORTHERN TANZANIA
}

\author{
ANN Muzuka \\ Institute of Marine Sciences, \\ University of Dar es Salaam, P.O. Box 668, \\ Zanzibar, Tanzania. \\ Fax: 255242233050 \\ e-mail: muzuka@zims.udsm.ac.tz \\ Accepted 4 March 2004
}

\begin{abstract}
A $29 \mathrm{~cm}$ long core recovered from a water depth of $5 \mathrm{~m}$ in a small closed lake located in the Empakai crater northern Tanzania, is used to document the contents of organic carbon and nitrogen, stable isotopes composition of organic carbon and nitrogen, and $C / N$ ratios and to infer climatic changes from these data. The $\delta^{13} \mathrm{C}$ and $\delta^{15} \mathrm{~N}$ values for this core, which averages $16.5 \pm 2.11$ and $11.0 \pm 5.6 \mathrm{l}$ respectively, show a general downcore decrease below $5 \mathrm{~cm}$. However, within this general trend, two peaks enriched in ${ }^{13} \mathrm{C}$ are observable at about $8 \mathrm{~cm}$ and $13 \mathrm{~cm}$. The peak at about $13 \mathrm{~cm}$ corresponds also to a zone depleted in ${ }^{15} \mathrm{~N}$ values. The general downcore trend can be attributed to systematic changes in relative proportion between $C_{3}$ and $C_{4}$ types of organic matter (OM), resulting from climatic changes or nutrient changes and shift between algae and higher plants. The lower most section containing the most depleted values can be attributed either to high input of autochthonous material owing to wetter/humid conditions or high contribution of $C_{3}$ high land plant materials in response to increase in forest cover. The general downcore decrease in ${ }^{13} \mathrm{C}$ values can also be interpreted to indicate that precipitation and vegetation cover in the area has been declining over time, and occasionally drought has been intense particularly during two zones that are characterized by enrichment in ${ }^{13} \mathrm{C}$. The upper $5 \mathrm{~cm}$ is characterized by near constant values of ${ }^{13} \mathrm{C}$ and ${ }^{15} \mathrm{~N}$ with isotope values as high as $-13.15 \%$ and $22.15 \%$ respectively. High enrichment in ${ }^{15} \mathrm{~N}$ in the upper $5 \mathrm{~cm}$ could be attributed to denitrification and ammonium volatilization processes, while enrichment in ${ }^{13} \mathrm{C}$ in the upper $5 \mathrm{~cm}$ could be attributed to high proportion of $\mathrm{C}_{4}$ type of $\mathrm{OM}$ and/or utilization of $\mathrm{HCO}_{3}^{-}$by phytoplankton during synthesis of OM. This site is also characterized by high concentrations of organic carbon (averaging 7.8 $2.0 \%$ ) and nitrogen (averaging $0.8 \pm 0.3 \%$ ). A smell of hydrogen sulfide detected in water samples collected at approximately $20 \mathrm{~m}$, suggest that there is enhanced preservation of $O M$ in the lake under anoxic condition. The $C / N$ ratios values, which average 12.2 \pm 2.3 , increase downcore to the base of the core owing to preferential loss of nitrogen containing compounds during diagenesis.
\end{abstract}

\section{INTRODUCTION}

Several workers have documented climatic changes for the past 1000 years in the East African region using various parameters (Nicholson 2000, Barker et al. 2000, Cole et al. 2000, Verschuren et al. 2000, Holmgren et al. 2001, Johnson et al. 2001, Lee-Thorp et al 2001). Johnson et al. (2001) have documented climatic variability as recorded by diatoms in Lake Malawi for the past 700 years, while Cole et al (2000) have used $\delta^{18} \mathrm{O}$ and $\delta^{13} \mathrm{C}$ record in corals off Malindi to document changes in sea surface temperature for the past 200 years. Verschuren et al. (2000) have used lake levels and salinity fluctuations in Lake Naivasha Kenya to infer rainfall and drought events. According to Verschuren et al. 
(2000), the East African region experienced drought during Medieval warm period and humid conditions during little ice age. Further south in South Africa, Holmgren et al. (2001) using record of stalagmite from Cold air cave in the Makapansgat valley have shown that the southern Africa region experienced high temperature in $900 \mathrm{AD}$ and during Medieval warming at around 1500 AD. Lee-Thorp et al. (2001) documented differences in rainfall between East and South Africa. They documented that the Little Ice Age was cooler than today by about $0.6^{\circ} \mathrm{C}$. Moreover, Barker et al. (2000) have documented climatic changes for the past four millennia in the southern Tanzania using sediment cores recovered from Massoko crater. According to Barker et al. (2000), relatively dry episode persisted between 1000 and 400 years ago. An increase in precipitation occurred after 350 years ago. Furthermore, historical records and tales for the past 300 years have been used to inferred climatic changes in the East African region (Nicholson 2000). However, none of the above studies have used the stable isotopes of organic carbon and nitrogen in conjunction with the contents of organic carbon and nitrogen to document climatic changes in the region over the past 1000 years. Therefore, this work present first geochemical results of the contents of organic carbon and nitrogen, stable isotopes composition of organic carbon $\left(\delta^{13} \mathrm{C}\right)$ and nitrogen $\left(\delta^{15} \mathrm{~N}\right)$, and $\mathrm{C} / \mathrm{N}$ ratios from the Empakai crater. Furthermore, these data are used to infer climatic changes that have taken place over the past 1000 years.

\section{METHODOLOGY \\ Study Area}

The Empakai crater, which is located at latitude $2^{\circ} 54^{\prime} \mathrm{s}$ and longitude $35^{\circ} 50^{\prime} \mathrm{E}$, lie within the north-eastern corner of the Ngorongoro Conservation Area Authority in northern Tanzania (Fig. 1). It is the northernmost caldera in the Crater Higlands and is about 10 kilometres south of the Oldonyo Lengai. The northern and eastern slopes of the Empakai crater rise from the floor of the Great East African rift valley, and the southern and western slopes are bordered by the highlands. The caldera's diameter is about $7 \mathrm{~km}$, and the caldera floor contains an alkaline lake about $79 \mathrm{~m}$ deep and 2 miles $(3.2 \mathrm{~km})$ wide. Near its south shore are two small ponds and several streams enter the main lake. The elevation of the caldera floor at the shore of the lake is about $2230 \mathrm{~m}$. The caldera rim is uneven, rising from an elevation of about $2510 \mathrm{~m}$ in the east to about $3260 \mathrm{~m}$ in the west (Frame 1982).

Like other parts of Tanzania, which are climatically characterized by two dry and wet seasons, this northern part of the country receives rain during the months of October through December and March through June. In Tanzania, rainfall is not evenly distributed, with central Tanzania (which include Dodoma and Singida regions) and large part of Arusha region in the northern Tanzania receiving far less rainfall relative to other parts of the country. Currently, this northern part of Tanzania receives less than $1000 \mathrm{~mm}$ of rain per year. Because of large herds of both domestic and wild animals the area is experiencing severe erosion. The sedimentation rates in the crater as well as other lakes located in this region are poorly known.

Geologically, the study area is studded by Neogene volcanic rocks and Quaternary lake beds (Harris 1961). The volcanic rocks are basaltic in nature. Furthermore, the lake is alkaline in nature and concentration of the major cations is high (see results section Table 1).

The vegetation of the Empakai Crater and its outer slopes is varied. On the western rim, vegetation is generally bushed grassland containing sagebrush-like Artemisia afra (George and Frame 1976). A small evergreen forest, which consists almost exclusively of Hagenia abyssinica trees, is found on the eastern rim. The lower eastern and northern rims are blanketed with a mosaic of dry 
evergreen forest dominated by Maesa lanceolata, Teclea simplicifolia, and Ficus thonningii (Frame 1982). Also these areas are studded by fire-induced bushland, and grassy glades (George and Frame 1976). To the west of the lake is rolling bushed grassland formerly in area of Arusha cultivation.
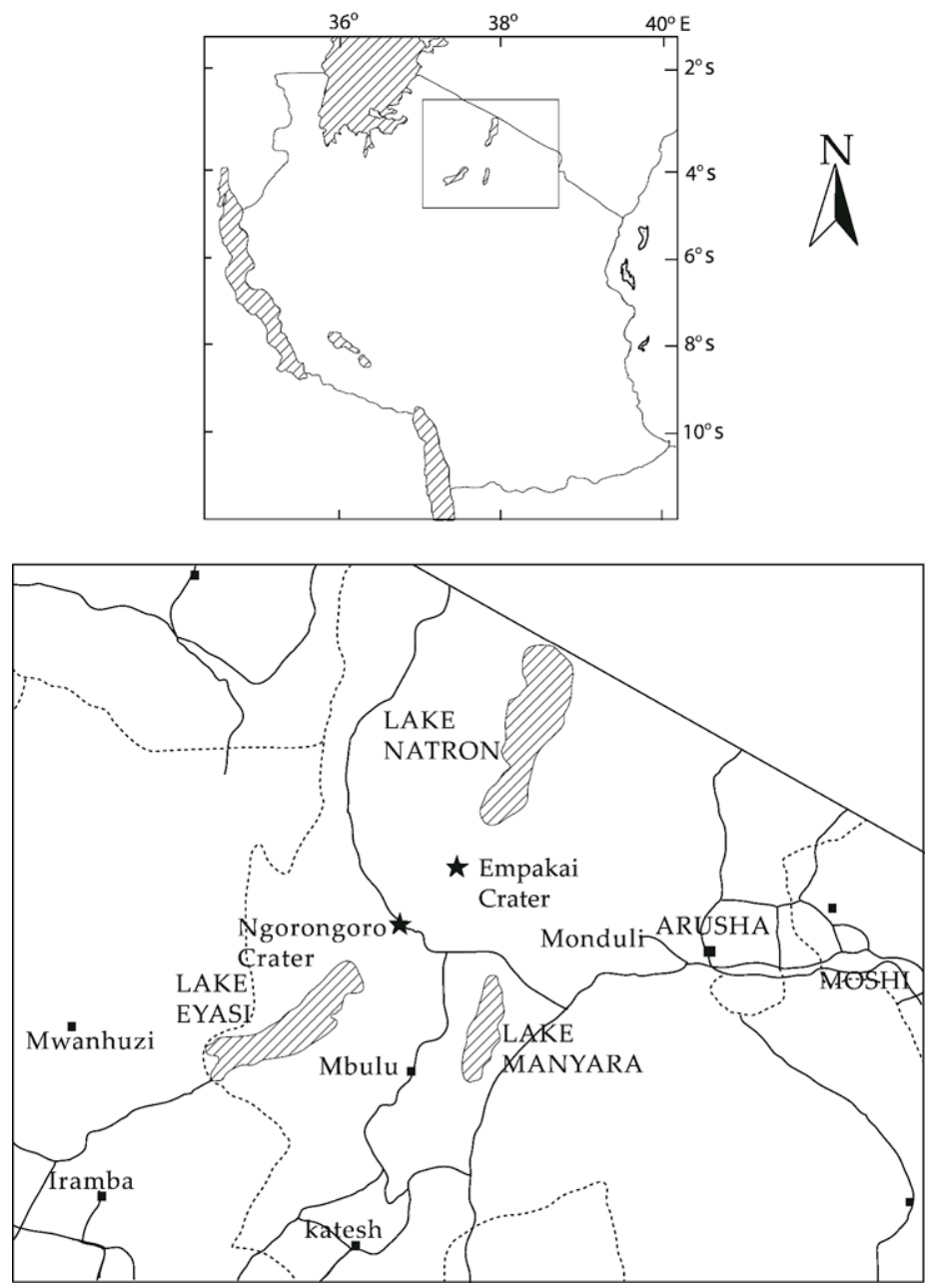

Figure 1: A map showing location of the study area.

\section{Sediment Core Stratigraphy}

A $29 \mathrm{~cm}$ long sediment core was recovered from a water depth of $5 \mathrm{~m}$ in the eastern side of lake Empakai using a lightweight gravity corer (Fig. 1). Sediments recovered at this site are dark in colour with high water content that decrease downcore to the base of the core (Fig. 2). The core was sub-sampled every $1 \mathrm{~cm}$ and each sample represent a homogenate of $1 \mathrm{~cm}$ thick. Two accelerate mass spectrometer (AMS) ${ }^{14} \mathrm{C}$ dates on total organic matter for a core collected from a nearby site (approximately $20 \mathrm{~m}$ ) at water depth of $8 \mathrm{~m}$ is available $(14-15 \mathrm{~cm}$ :

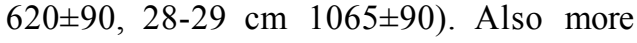
dates have been obtained on cores collected during subsequent field campaign from the same area, and ${ }^{14} \mathrm{C}$ data for core EMP LIV 4 
at $26-27 \mathrm{~cm}$ is $920 \pm 85$. Assuming that there is no contribution of old carbon and dissolved $\mathrm{CO}_{2}$ in the lake was in equilibrium with the atmospheric $\mathrm{CO}_{2}$, the ${ }^{14} \mathrm{C}$ data shows that sedimentation rate in this lake is low and is about $26 \mathrm{~cm} / \mathrm{ka}$. With the rim being covered by vegetation and lack of rivers flowing into the crater, this is likely.

\section{Geochemical Analysis}

The stable isotope compositions of total organic carbon (TOC) and nitrogen as well as the contents of TOC and nitrogen were determined at the Department of Geology and Geochemistry, University of Stockholm. All the isotope data are reported in $\delta$-values relative to the PDB and atmospheric nitrogen respectively. TOC and nitrogen are reported in dry weight percentage. Reproducibility of TOC and nitrogen is within $\pm 2 \%$ and $\pm 0.1 \%$ respectively while that of stable isotopes of TOC and nitrogen are within \pm 0.11 .

\section{RESULTS}

The values of the stable isotope compositions of TOC, which range from $20.3 \%$ to $-13.1 \%$, average $-16.5 \pm 2.1 \%$. The upper $5 \mathrm{~cm}$ have high but constant OC isotope values (Fig. 3). Below $5 \mathrm{~cm}$, the $\delta^{13} \mathrm{C}$ values show a generally downcore decrease to $25 \mathrm{~cm}$ (Fig. 2). This general trend is interrupted by two zones, which are enriched in ${ }^{13} \mathrm{C}$, at $8 \mathrm{~cm}$ and $13 \mathrm{~cm}$ (Fig. 2). Lowest $\delta^{13} \mathrm{C}$ values are found between 17 and $25 \mathrm{~cm}$ (Fig. 2). Below $25 \mathrm{~cm}$, the stable isotope values of organic carbon show a systematic downcore increase to the base of the core (Fig. 2). This parameter shows a weak positive correlation with ${ }^{15} \mathrm{~N}$, but display a negative correlation with the $\mathrm{C} / \mathrm{N}$ ratios (Fig. 3). Contrary to the $\delta^{13} \mathrm{C}$ values, the $\mathrm{C} / \mathrm{N}$ ratios values, which average $12.2 \pm 2.3$, show a general downcore increase (Fig. 2).

Nitrogen isotope values show a general downcore decrease with one peak that is characterized by most depleted values between 9 and $12 \mathrm{~cm}$ (Fig. 2). This zone corresponds to enrichment in ${ }^{13} \mathrm{C}$ values (Fig. 2). Moreover, the upper $5 \mathrm{~cm}$ have $\delta{ }^{15} \mathrm{~N}$ values that are relatively high and range from $16 \%$ to $22 \%$ (Fig. 2).

The content of $\mathrm{OC}$ and nitrogen, which averages $7.8 \pm 2.0 \%$ and $0.78 \pm 0.3 \%$, respectively, is high in the upper $5 \mathrm{~cm}$ (Fig. 2). High OC and nitrogen values in the upper $5 \mathrm{~cm}$ are associated with high but near constant isotope values of $\mathrm{OC}$ and nitrogen (Fig. 2) and low $\mathrm{C} / \mathrm{N}$ ratios (Fig. 2 ). Below $5 \mathrm{~cm}$, nitrogen content is nearly constant at $0.6 \%$ while $\mathrm{OC}$ content show two steps increase to $25 \mathrm{~cm}$ followed by a decrease to the base of the core (Fig. 2). Peaks of the OC content lag slightly those of ${ }^{13} \mathrm{C}$ values (Fig. 2). A scatter plot of $\mathrm{OC}$ versus nitrogen content show a positive correlation (Fig. 3). 


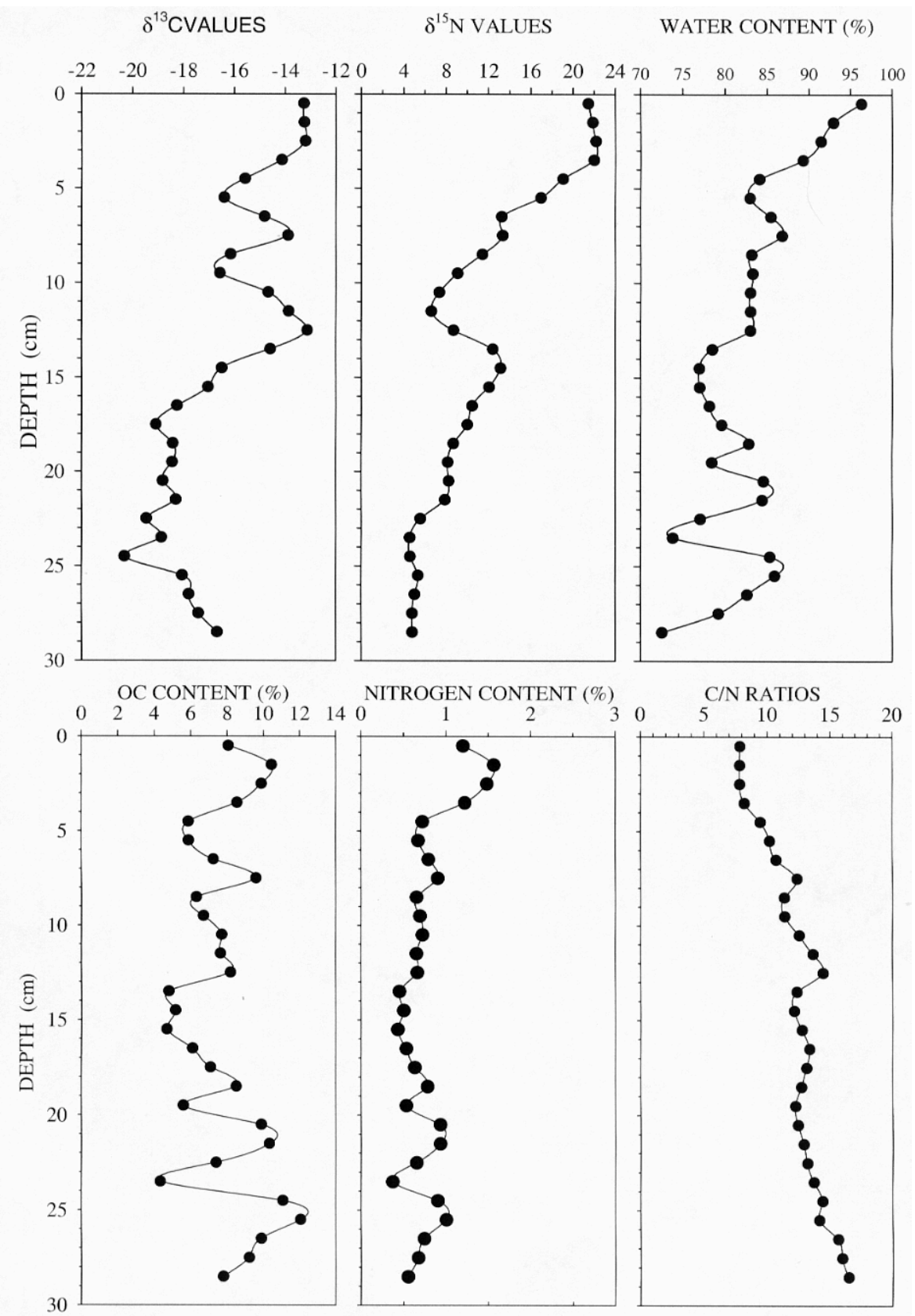

Figure 2. Downcore variation in organic $\delta^{13} \mathrm{C}$ (left upper pannel), $\delta^{15} \mathrm{~N}$ (central upper panel), water content (upper panel), contents of organic carbon (left lower panel) and nitrogen, and $\mathrm{C} / \mathrm{N}$ ratios (right lower panel) in a sediment core recovered from the Empakai Crater lake. 

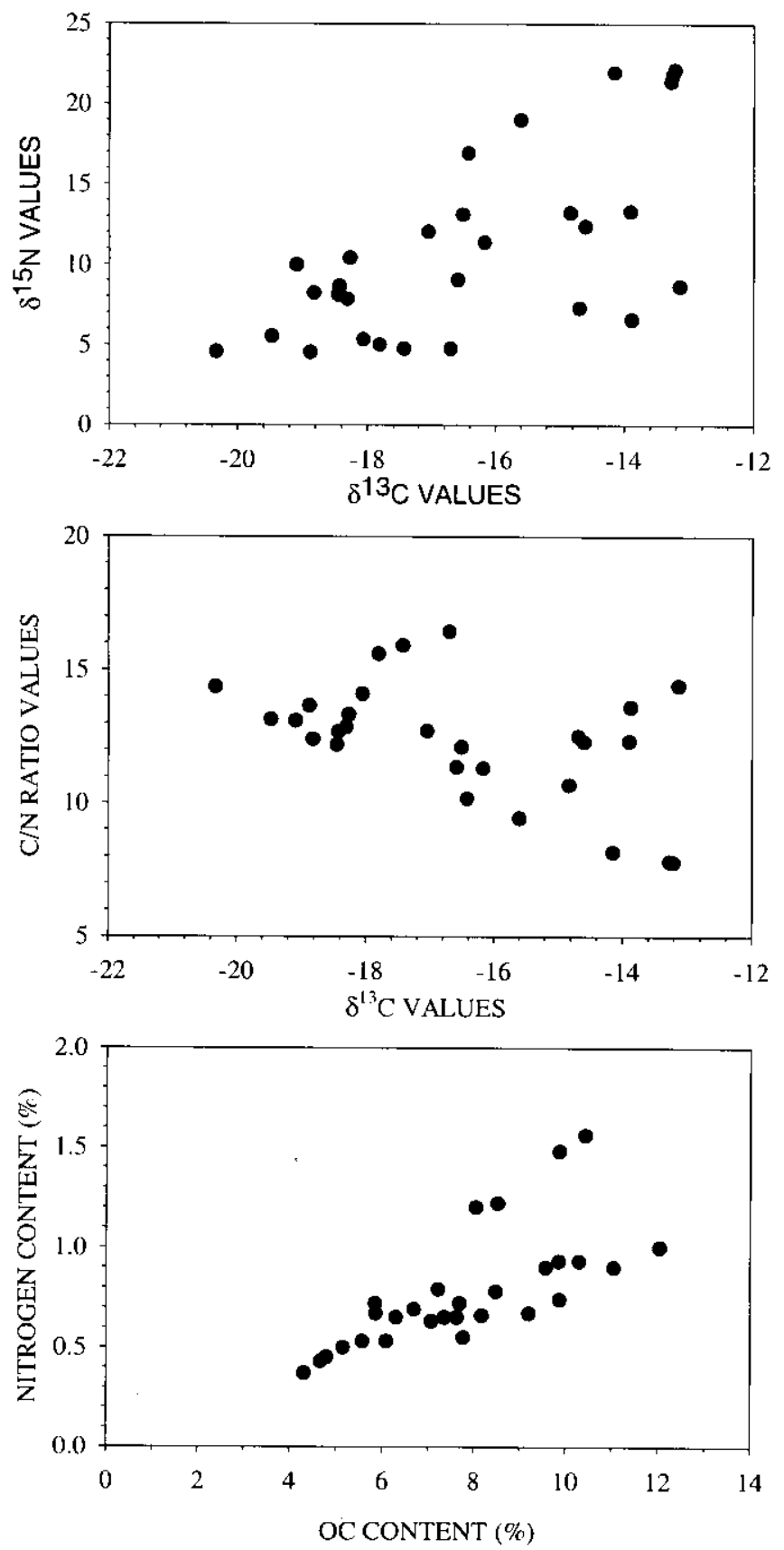

Figure 3. Scatter plotts for various parameters. The plots of organic carbon versus nitrogen, and $\delta^{13} \mathrm{C}$ versus $\mathrm{C} / \mathrm{N}$ ratio values show positive and negative correlation respectively. 


\section{DISCUSSION}

The isotope values of $\mathrm{OC}$ and nitrogen in the upper $5 \mathrm{~cm}$ average $-13.9 \%$ and $21.3 \%$ respectively, while the contents of $\mathrm{OC}$ and nitrogen averages $8.5 \%$ and $1.24 \%$ respectively. High nitrogen isotope values of $21.3 \%$ have been rarely reported in the lacustrine environment. Generally, nitrogen stable isotope values of sedimentary organic material in lake environment has been observed to range from $0 \%$ to $10 \%$ (Letollé, 1980; Talbot and Lærdal, 2000). Therefore, high $\delta^{15} \mathrm{~N}$ values observed in the upper section of the core calls for another explanation. In the marine environment, high isotope values of similar magnitude have been reported in the Arabian Sea for material recovered from oxygen minimum zone (Altabert et al. 1999, Muzuka et al. 1991). High isotope values in the Arabian Sea have been attributed to denitrification process. Field observation indicates that the lake is covered by green layer of algae early in the morning and also there are a large number of flamingo living in the crater. Three species of phytoplankton of the family Oscillatoriaceae, namely Spirulina spp., Lyngbya spp. and Oscillatoria spp are abundant in the lake. Nitrogen isotope compositions of these phytoplankton species are not known. Because the lake receive a lot of flamingo droppings and high primary productivity, input of organic matter to the lake is very high and denitrification is highly likely. A smell of hydrogen sulfide encountered while collecting water samples at a water depth of $20 \mathrm{~m}$ proves the existence of anoxic conditions. Because sulphate reduction process normally takes place after denitrification has taken place, it is clear that there is enough labile organic matter to support denitrification in this lake. Therefore, high values of ${ }^{15} \mathrm{~N}$ can be attributed to dentitrification process. With a sedimentation rate of about $26 \mathrm{~cm} / \mathrm{ka}, 5 \mathrm{~cm}$ represent a period of about 200 years and high ${ }^{15} \mathrm{~N}$ values represent onset of denitrification process in the lake, and probably a period when flamingos started to colonise the lake.
However, there are other processes that can cause formation of organic material enriched in ${ }^{15} \mathrm{~N}$, such as ammonia volatilization. The isotope fractionation factor for ammonia volatilization is about 1.034 , and this process is significant in waters that have $\mathrm{pH}$ greater than 8.5 and its impact is even higher on dissolved inorganic nitrogen if the $\mathrm{pH}$ exceeds 9 (Collister and Hays 1991). The $\mathrm{pH}$ of the Empakai crater lake is high and range from 10 to 12 , and thus, ammonia volatilization processes could contribute significantly to the observed enrichment in ${ }^{15} \mathrm{~N}$. Most likely, both processes of denitrification and ammonia volatilization account for the observed high nitrogen isotope values in the upper $5 \mathrm{~cm}$. Onset of ammonia volatilization represented by high ${ }^{15} \mathrm{~N}$ values could represent a period when the lake became alkaline owing to persistent aridity in the area. If this is true, then irrigation system in the Engaruka, which is close to the present study area, was probably abandoned because of drier climatic conditions.

From isotopic point of view, a mean of $13.9 \%$ for the stable isotope values of organic carbon in the upper $5 \mathrm{~cm}$ would suggest that deposited sediments are mainly derived from $\mathrm{C}_{4}$ type of material. This inference would be backed by the fact that the isotopic composition of lacustrine phytoplankton is highly variable and $\delta$ values fall within the range of $\mathrm{C}_{3}$ terrestrial plants that averages $-27 \%$ and sometime are even less (LaZerte and Szalados 1982, Aravena et al. 1992, de Giorgio and France 1996, Tenzer et al. 1997). In contrast the $\delta{ }^{13} \mathrm{C}$ values for $\mathrm{C}_{4}$ plants averages $-13 \%$ (e.g. Deines 1980, Prahl et al. 1994, Muzuka 1999). However, because of lower $\mathrm{C} / \mathrm{N}$ ratio values that are similar to those of phytoplankton shows that material deposited on the lake floor are not derived from $\mathrm{C}_{4}$ land plants. The observed high $\delta^{13} \mathrm{C}$ values could be attributed either to the utilization of isotopically enriched carbon such as carbonate and bicarbonate during 
photosynthesis or diagenetic alteration of organic matter when compounds enriched in ${ }^{12} \mathrm{C}$ are removed. However, the latter option is normally associated with increase in the $\mathrm{C} / \mathrm{N}$ ratios, which are less than 10 in lacustrine phytoplankton material and higher than 10 in $\mathrm{C}_{4}$ plants (Hedges et al. 1986; Meyers 1994). Therefore most likely high $\delta^{13} \mathrm{C}$ values are a result of utilization of bicarbonate during OC synthesis. Phytoplankton tend to utilize bicarbonate when dissolved $\mathrm{CO}_{2}$ is limiting, and such situation occurs in lakes where mixing is limited (O'Leary 1988). As pointed out previously, the smell of hydrogen sulphide detected at a water depth of $20 \mathrm{~m}$ suggests that a large part of the water column of the Empakai Crater Lake is anoxic and stratified. Also high evaporation rate over precipitation is normally associated with isotope enrichment in dissolved carbon owing to limitation to $\mathrm{CO}_{2}$ dissolution, and currently the area is experiencing high evapotransipiration than precipitation.

The stable isotopes of TOC show a general downcore decrease with the exception of interruption of ${ }^{13} \mathrm{C}$ enrichment at around 13 $\mathrm{cm}$ and towards the base of the core (Fig. 3). This general downcore decrease culminating with a zone depleted in ${ }^{13} \mathrm{C}$ values between $15 \mathrm{~cm}$ and $25 \mathrm{~cm}$ can be attributed to either increase in the relative proportion in $\mathrm{C}_{3}$ plant material or diagenetic alteration of isotopic signature. There is a change of about $7 \%$ from the upper ${ }^{13} \mathrm{C}$ enriched to lower depleted core sections. Diagenetic alteration of stable isotope signatures has been a controversial issue. In some studies it has been suggested that a change of up to $2 \%$ can be attributed to diagenetic alteration, while others have not observed any isotope change (Meyers 1994). Thus, such a huge change cannot be attributed to diagenetic alteration of organic matter. Increase in the quantity of $\mathrm{C}_{3}$ type of organic matter downcore is the most likely scenario, and it implies that there has been an increase in either phytoplankton productivity or increase in the land cover by $\mathrm{C}_{3}$ plants. Both sources, which are isotopically inseparable, require an increase in the amount of precipitation and thus high lake levels. Few workers have documented changes in precipitation in the East African region for the past 1000 years (e.g. Verschuren et al. 2000). The work of Verschuren et al. (2000) has documented that Little ice age (1270$1850 \mathrm{AD}$ ) was wetter, but was interrupted in between by three prolonged dry periods $(1380-1420,1560-1620$, and 1760-1840) than it is today. Highest lake levels occurred between 1670 and 1770. Since 1894, the lake levels have been falling (Verschuren et al 2000). Therefore, a zone depleted in ${ }^{13} \mathrm{C}$ probably correspond to the Little ice age period when precipitation was high and could also be related to intensification in the monsoon winds.

Two zones enriched in ${ }^{13} \mathrm{C}$ at 8 and $13 \mathrm{~cm}$ (Fig. 3), can be attributed to deposition of high proportion of $\mathrm{C}_{4}$ plant organic material or utilization of carbon enriched in ${ }^{13} \mathrm{C}$ during photosynthesis such as bicarbonate when dissolved $\mathrm{CO}_{2}$ is limiting. Such high values could also result from high contribution of submerged macrophytes, which have been observed to have isotope values that are enriched in ${ }^{13} \mathrm{C}$ relative to terrestrial $\mathrm{C}_{3}$ plants (LaZerte and Szalados 1982). However, macrophytes, which thrive well in shallow photic zones, were not observed during sampling. Thus, enrichment in ${ }^{13} \mathrm{C}$ up to $13 \%$ observed at this depth interval can be attributed to high proportion of $\mathrm{C}_{4}$ derived organic material. This implies that this period was associated with a drought. With a sedimentation rate of about $26 \mathrm{~cm} / \mathrm{ka}, 13 \mathrm{~cm}$ correspond to about 1450 , a period considered to be dry (Verschuren $e t$ al. 2000).

\section{CONCLUSION}

The upper $5 \mathrm{~cm}$ is characterized by enrichment in ${ }^{13} \mathrm{C}$ and ${ }^{15} \mathrm{~N}$ as well high content of OC and nitrogen. The $\delta^{15} \mathrm{~N}$ and $\delta^{13} \mathrm{C}$ values are as high as $221 \%$ and $-13 \%$ respectively. High nitrogen isotope values greater than $16 \%$ can be attributed to the 
denitrification and/or ammonia volatilization processes. Onset of denitrification process could probably indicate period when the lake was first colonized by the flamingo, which resulted into input of organic rich guano. Furthermore, ammonia volatilization that takes place in aquatic environment with $\mathrm{pH}$ of 9 or higher could represent a period when the area started to experience higher evaporation rates than precipitation and thus aridity. Inferred aridity could be responsible for the abandonment of a well-developed irrigation system in the Engaruka area.

Below $5 \mathrm{~cm}$, the stable isotopes of $\mathrm{OC}$ show a downcore decrease to about $25 \mathrm{~cm}$. Two peaks enriched in ${ }^{13} \mathrm{C}$ at $8 \mathrm{~cm}$ and 13 $\mathrm{cm}$ interrupt this general trend. The general downcore decrease in ${ }^{13} \mathrm{C}$ can be attributed to a progressive increase in relative proportion of $\mathrm{C}_{3}$ type of material owing to increase in rainfall or lake levels. The two peaks enriched in ${ }^{13} \mathrm{C}$ contain high proportion of $\mathrm{C}_{4}$ type of organic matter and represent a period of aridity. Lowest isotope values centred between 15 and $25 \mathrm{~cm}$ represent wetter or humid conditions where lake levels were high.

OC and nitrogen contents in the upper 29 $\mathrm{cm}$ of the core are high, and thus, the lake is experiencing enhanced preservation of organic matter under anoxic condition.

\section{ACKNOWLEDGEMENT}

The author is highly grateful for the laboratory assistance accorded to him by Prof. Peter Torssander of the Department of Geology and Geochemistry, Stockholm University, and the administrative personnel of the Ngorongoro Conservation Area Authority (NCAA) for their cooperation and permission to work in the area. I am particularly grateful to Mr. P. Lelo, and $\mathrm{Mr}$. Mkonyi of the NCAA headquarters, and Mr. Thomas of NCAA Nainokanoka ranger post. I am also grateful for good cooperation and assistance by Prof. Wibjön Karlén and Maria Lyner of the Department of Physical Geography, Stockholm University.

\section{REFERENCE}

Altabet MA, Murray DW and Prell W L 1999 Climatically linked oscillations in Arabian Sea denitrification over the past 1 m.y.: Implications for the marine N cycle. Paleoceanography 14: $732-743$.

Aravena R, Warner B, MacDonald G L and Hanf K 1992 Carbon isotope compositions of lake sediments in relation to lake productivity and radiocarbon dating. Quaternary Research 37: 333-345.

Barker P, Telford R, Merdaci O, Williamson D, Taieb M, Vincens A and Gibert E 2000 The sensitivity of a Tanzanian crater lake to catastrophic tephra input and four millennia of climate change. The Holocene 10: 303-310.

Cole JE, Dunbar. RB, McClanahan TR, and Muthiga NA 2000 Tropical Pacific forcing of decadal SST variability in the western Indian Ocean over the past two centuries. Science 287: 617 - 619 .

Collister JW and Hays JM 1991 A preliminary study of the carbon and nitrogen isotope biogeochemistry of lacustrine sedimentary rocks from the Green River Formation, Wyoming, Utah and Colorado. United States Geological Survey Bulletin 1973-AG:C1-C16.

Deines ET 1980 The isotopic composition of reduced organic carbon, in $\mathrm{P}$. Fritz, and J.Ch. Fontes (eds.) Handbook of Environmental Isotope Geochemistry, Vol. 1A. Elsevier, New York, pp. 329-406.

de Giorgio PA and France RL 1996 Ecosystem-specific patterns in the relationship between zooplankton and POM or microplankton $\delta^{13} \mathrm{C}$. Limnology and Oceanography 41: 359-365.

Frame GW 1982 Wild mammal survey of Empakai crater area. Tanzania Notes and Records 88/89: 41-55. 
George W and Frame LH 1976 Empakai Crater ecosystem project. Explorers Journal September: 112-117.

Harris JF 1961 Summary of the Geology of Tanganyika Part IV Economic Geology Mem No. 1. Geological Survey, Tanganyika.

Hedges JI, Clark WA, Quay PD, Richey JE, Devol, AH, and Santos UM 1986 Compositions and fluxes of particulate organic material in the Amazon River. Limnology and Oceanography 31: 717-738.

Holmgren K, Tyson PD, Moberg A, and Svanered O 2001 A preliminary 3000-year regional temperature reconstruction for South Africa. South African Journal of Science 97: 49-51.

Johnson TC, Barry SL, Chan Y, and Wilkinson P 2001 Decadal record of climate variability spanning the past $700 \mathrm{yr}$ in the Southern tropics of East Africa. Geology 29: 83-86.

LaZert B and Szalados JE 1982 Stable carbon isotope ratio of submerged freshwater macrophytes. Limnology and Oceanography 27: 413-418.

Lee-Thorp JA, Holmgren K Lauritzen S.-E, Linge H, Moberg A Partridge TC, Stevenson C, and Tyson PD 2001 Rapid climate shifts in the southern African interior throughout the mid to late Holocene. Geophysical Research Letters 28: 4507-4510.

Letollé R 1980 Nitrogen-15 in natural environment. In: Fritz, P. And Fontes, J. (Eds) Handbook of Environmental Geochemistry, Vol. 1. Elsevier Sci. Publ., New York, p. 407-433.

Meyers PA 1994 Preservation of elemental and isotopic source identification of sedimentary organic matter. Chemical Geology 114: 289-302.

Muzuka ANN 1999 Isotopic compositions of tropical East African flora and their potential as source indicators of organic matter in coastal marine sediments. Journal of African Earth Sciences 28: 757-766.

Muzuka ANN, Macko SA, and Pedersen TF 1991 Stable carbon and nitrogen isotope compositions of organic matter from Sites 724 and 725, Oman Margin. In: Prell, W. L., Niitsuma, N., et al., Proceedings of the Ocean Drilling Program, Scientific Results, Vol. 117. College Station, Texas, p. 571-586.

Nicholson SE 2000 The nature of rainfall variability over Africa on time scales of decades to millenia. Global and Planetary Change 26: 137-158.

$\mathrm{O}=$ Leary $\mathrm{MH} 1988$ Carbon isotopes in photosynthesis. Bioscience 38: 328336

Prahl FG, Ertel JR, Goni MA, Sparrow MA, and Eversmeyer B 1994 Terrestrial organic carbon contributions to sediments on the Washington margin. Geochimica et Cosmochimica Acta 58: 3035-3048.

Talbot MR and Lærdal T 2000 The late Pleistocene-Holocene

palaeolimnology of Lake Victoria, East Africa, based upon elemental and isotopic analyses of sedimentary organic matter. Journal of Paleolimnology 23: 141-164.

Tenzer GE, Meyers PA, and Knoop P 1997 Sources and distribution of organic and carbonate carbon in surface sediments of Pyramid Lake, Nevada. Journal of Sedimentary Research 67: 884-890.

Verschuren D, Laird KR, and Cumming BF 2000 Rainfall and drought in equatorial east Africa during the past 1,100 years. Nature 403: 410-414. 